\title{
The Hydroids collected by the "Huxley" from the North Side of the Bay of Biscay in August, 1906.
}

\author{
$\mathrm{By}$
}

\author{
Edward T. Browne.
}

(University College, London.)

With Plates I. and II. and one Figure in the Text.

\section{INTRODUCTION.}

The Hydroids collected on the northern edge of the Bay of Biscay during a five days' cruise in August, 1906, by Dr. E. J. Allen, were entrusted to me for examination. I thank my friend Dr. Allen for giving me the opportunity of working through the collection, which contained thirty-seven species, including two new species (Bimeria arborea and Bimeria biscayana) and several rare deep-sea forms.

Our knowledge of the area occupied by the British Hydroids has been increased by this cruise. All the species taken at six out of the eight stations have been previously recorded for the British area. It was only at the two stations over 400 fathoms that foreign species occurred. Bathymetrical distribution has also made an advance, as several species were taken at a depth considerably greater than that hitherto recorded for them.

I have followed Hincks's nomenclature very closely, because the names are so familiar to us, though I foresee that a day is not far distant when other generic names, which at present are only known to specialists, will have to be introduced into our faunistic lists.

The geographical distribution of nearly all the British species mentioned in this report has already been given by Dr. Allen in his paper on the "Fauna of the Eddystone Grounds," published in this journal in 1899 , so that it is scarcely necessary to repeat the same records again. But since that date several important works on Hydroids have been published, and from these I have selected such records as are of geographical and bathymetrical importance. 
LIST OF SPECIES, AND THE STATIONS AT WHICH THEY OCCURRED.

\begin{tabular}{|c|c|c|c|c|c|c|c|c|c|c|}
\hline & \multicolumn{2}{|c|}{$\begin{array}{l}\text { Station No. } \\
\text { Latitude, N. } \\
\text { Longitude, W. } \\
\text { Fathoms }\end{array}$} & \begin{tabular}{|c|} 
I. \\
$48^{\circ} 25^{\prime}$ \\
$6^{\circ} 28^{\prime}$ \\
75
\end{tabular} & $\begin{array}{c}\text { II. } \\
48^{\circ} 24^{\prime} \\
6^{\circ} 28^{\prime} \\
75\end{array}$ & \begin{tabular}{|c|} 
III. \\
$48^{\circ} 24^{\prime}$ \\
$6^{\circ} 33^{\prime}$ \\
75
\end{tabular} & $\begin{array}{c}\text { IV. } \\
47^{\circ} 48^{\prime} \\
7^{\circ} 25^{\prime} \\
109\end{array}$ & \begin{tabular}{|c|} 
V. \\
$47^{\circ} 48^{\prime}$ \\
$7^{\circ} 46^{\prime}$ \\
109
\end{tabular} & $\begin{array}{c}\text { VII. } \\
47^{\circ} 36^{\prime} \\
7^{\circ} 31^{\prime} \\
\dot{444}\end{array}$ & \begin{tabular}{|c|} 
IX. \\
$48^{\circ} 7^{\prime}$ \\
$8^{\circ} 13^{\prime}$ \\
240
\end{tabular} & $\begin{array}{c}\text { XIII. } \\
48^{\circ} 7^{\prime} \\
8^{\circ} 13^{\prime} \\
412\end{array}$ \\
\hline \multicolumn{11}{|c|}{ - GYMNOBLASTEA. } \\
\hline Bimeria nutans (Wright) & . & . & + & + & - & - & - & - & - & - \\
\hline ," vestita, Wright & . & . & - & + & - & - & -. & - & - & - \\
\hline ", arborea, n. sp. & . & . & - & - & - & - & - & - & - & + \\
\hline biscayana, n. sp. & & . & - & - & - & - & - & - & - & + \\
\hline Eudendrium ramosum ( $\mathrm{Li}$ & inn.) & & - & - & - & + & - & - & - & - \\
\hline Tubularia sp. ${ }^{2}$. & llas) & & - & + & - & - & - & + & - & + \\
\hline Tubularia sp. & ${ }^{\circ}$ & . & & & & & & & & - \\
\hline \multicolumn{11}{|c|}{ CALYPTOBLASTEA. } \\
\hline Clytia johnstoni (Alder) & & . & + & + & - & - & - & - & - & - \\
\hline Campanularia hincksii, A & & . & + & + & - & - & + & + & + & + \\
\hline $\begin{array}{r}\text { raridentata } \\
\text { Calycella fastigiata (Alde }\end{array}$ & , Alder & . & - & - & - & + & - & & - & - \\
\hline $\begin{array}{l}\text { Calycella fastigiata (Alde) } \\
\text { Lafoèa dumosa (Fleming) }\end{array}$ & r). & · & $\stackrel{+}{-}$ & $\bar{t}$ & - & $\begin{array}{l}+ \\
-\end{array}$ & $\bar{t}$ & $\overline{-}$ & $\stackrel{+}{-}$ & $\bar{t}$ \\
\hline ", fruticosa (M. Sars) & & : & + & $\begin{array}{l}+ \\
+\end{array}$ & - & - & - & - & - & + \\
\hline "' pinnata, G. O. Sar & & . & - & - & - & - & - & - & - & + \\
\hline Filellum serpens (Hassall & & & - & + & - & - & - & - & + & - \\
\hline Perisiphonia pectinata, $\mathrm{P}$ & ictet and & Bedot & - & - & - & - & - & - & - & + \\
\hline Cryptolaria humilis, Alln & &.$\quad$. & - & - & - & - & - & - & - & + \\
\hline Cuspidella grandis, Hincl & & & + & - & - & + & - & - & - & - \\
\hline ,' costata, Hinck & & & + & - & - & - & - & - & - & - \\
\hline Halecium sessile, Norman & & & - & - & - & - & - & - & - & + \\
\hline Sertularella polyzonias (L & inn.) & & + & + & + & + & + & - & + & - \\
\hline ,, gayi (Lamour & & & & - & - & - & - & + & & + \\
\hline Diphasia pinaster (Ellis a & nd Solan & der) & + & + & - & + & + & - & - & - \\
\hline ," tamarisca (Linn & & . & + & + & - & - & - & - & - & - \\
\hline pinnata (Pallas) & & . & - & - & + & - & - & - & - & - \\
\hline ," alata, Hincks & & & - & - & - & + & + & - & - & - \\
\hline Sertularia abietina (Linn. & & : & - & + & + & - & - & - & + & - \\
\hline Hydrallmania falcata (Li) & nn.) & & + & - & - & - & - & - & - & - \\
\hline Plumularia elegantula, $\mathrm{G}$ & O. Sars & & - & - & - & - & - & + & - & \\
\hline ,, setacea (Ellis) & & & + & - & - & - & 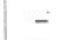 & . & & \\
\hline ,, frutescens (Ell & is and Sol & lander) & - & - & - & - & - & - & - & + \\
\hline Antennularia antennina ( & Linn & & + & + & - & - & - & - & - & - \\
\hline Antennopsis norvegica & $\begin{array}{l}\text { narck) } \\
\text { O. Sars }\end{array}$ & & $\overline{-}$ & $\stackrel{+}{-}$ & - & - & $\overline{-}$ & $\overline{-}$ & $\overline{-}$ & $\overline{+}$ \\
\hline Aglaophenia myriophyllu & m (Linn. & & + & + & - & - & - & - & - & - \\
\hline
\end{tabular}

\section{STATIONS AND THEIR CHARACTERISTIC HYDROIDS.}

Station I. East side of Parson's Bank. 75 fathoms.

At this station an ordinary dredge was dragged for about a mile over a sandy bottom. Here were found rooted in the sand Aglaophenia myriophyllum and Antennularia antennina, which may be regarded as the characteristic Hydroids of this ground. Attached to shells and worm-tubes (Chotopterus) were colonies of Sertularella polyzonias, Diphasia pinaster, and Diphasia tamarisca, and on a broken pecten shell was a nice compact colony of Cuspidella grandis. Eight other 
species were found, nearly all of them being fixed to the larger Hydroids, Aglaophenia, Antennularia, and Sertularella.

STATION II. This station is a continuation of Station I., but here an Agassiz trawl was used in the place of a dredge. There is a distinct decrease in the number of Aglaophenia myriophyllum and Antennularia antennina. The dredge, no doubt, is a better instrument for digging out these rooted Hydroids than the trawl. On the other hand, Sertularella polyzonias and Diphasia pinaster, both attached to worm-tubes, show an increase in number in the haul taken by the trawl over that of the dredge.

The species taken at this station are nearly the same as those found at the first station, but Sertularia abietina is an addition. The latter is a fine old colony with branches thickly covered with other small Hydroids.

Station III. A large otter trawl was used at this station, which was a few miles south-west of Station II. The trawl brought up a fine large colony of Diphasia pinnata, and a large colony of Sertularia abietina. Upon the latter were attached small colonies of Sertularella polyzonias.

The great falling off in the number of colonies at this station must be put down to the use of the otter trawl.

All the Hydroids taken at Stations I., II., and III. have been recorded for the Eddystone Grounds. There is a remarkable similarity between the Hydroid fauna of the two regions, though they are far apart.

Station IV. Near La Chapelle Bank. 109 fathoms. Bottom deposit-coarse sand and broken shells.

This station was about fifty miles to the south-west of Station III., and here a dredge was used. It brought up a large colony of Sertularella polyzonias attached to a worm-tube, a very fine colony of Diphasia alata, and a small colony of Diphasia pinaster on a worm-tube. Four other species were found upon these Hydroids.

Station V. 109 fathoms. Bottom deposit-coarse sand and shells. An Agassiz trawl was used at this station, which was not far from Station IV.

Here Diphasia alata, Sertularella polyzonias, and Diphasia pinaster were again the principal Hydroids. Diphasia alata may be regarded as the characteristic Hydroid for Stations IV. and V. It was not taken at any of the other stations, and it has not been recorded for the Eddystone Grounds.

Station VII. Over 444 fathoms.

Although this station was only a few miles south of Station V., the water is about four times as deep. An Agassiz trawl was used, but it 
brought up very few Hydroids. Here were found some large colonies of Sertularella gayi, to which are fixed a few colonies of Campanularia hincksii, a large branch of Eudendrium rameum, and fragments of Plumularia elegantula.

Station IX. 240 fathoms. Bottom deposit-fine sand.

This station belongs to another area, about forty miles north-west of Station VII. Only a few Hydroids were taken, and all were broken into fragments. Sertularia abietina and Sertularella polyzonias appear to be the principal forms.

Station XIII. 412 fathoms. Bottom deposit-sand, mud, and hard ground.

This station was not far from Station IX., but it was on the side of the Atlantic slope. For Hydroids it is certainly the most interesting of all the stations, as it was just beyond the range of the British Hydroid fauna. At all the other stations every Hydroid (except Plumularia elegantula at Station VII.) had been previously recorded within the British area, and described in Hincks's classical monograph.

At this station an Agassiz trawl was used, and it struck a large bed of the coral Lophohelia prolifera, to which many Hydroids were attached.

Amongst the larger Hydroids were Eudendrium rameum, Halecium sessile, Sertularella gayi, and two new species of Bimeria (B. arborea, B. biscayana). The foreign species include Laföea pinnata, Perisiphonia pectinata, Cryptolaria humilis, Plumularia elegantula, and Antennopsis norvegica. The occurrence of Perisiphonia pectinata and Cryptolaria humilis extends their geographical range further north.

Several species h:ve their bathymetrical distribution considerably extended into deeper water, namely, Eudendrium rameum, Campanularia hincksii, Halecium sessile, Plumularia elegantula, Plumularia setacea, and Plumularia frutescens.

Two more foreign species were taken, which are not mentioned in this report. They look something like a Cryptolaria, but possess an operculum. If the colonies had been complete and in better condition I would have described them.

\section{GYMNOBLASTEA. \\ BOUGAINVILLID $\mathbb{E}$.}

Character of the family. Trophosome-hydranths with conical hypostome, tentacles filiform in a single verticil. Gonosome-gonophores, planoblasts, or hedrioblasts (Allman, 1888). 
BIMERIA, Wright, 1859.

Generic character. Trophosome-hydrocaulus well developed, usually erect and branching; hydranths fusiform. Gonosomegonophores in the form of sporosacs developed upon the hydrophyton.

The above description of the genus is almost identical with that given by Torrey (1902), who has emended Hincks's description and broadened it, so as to include the genus Garveia. According to Allman and Hincks, Bimeria is distinguished from Garveia by the perisarc, covering the lower part of the hydranth, extending over the proximal half of each tentacle, a character more suitable for a species than for a genus.

I am distinctly in favour of constituting the genus Bimeria in such a manner that it may stand in relation to Bougainvillia as Coryne does to Syncoryne, the trophosomes of the two genera being somewhat similar, but their gonosomes quite distinct, the former possessing sporosacs and the latter planoblasts.

It must be remembered that Bimeria vestita is the type species of the genus. Its trophosome in general appearance is very much like a Bougainvillia. Madame Motz-Kossowska (1905) has, however, transferred Bimeria vestita to the genus Perigonimus, which, like Bougainvillia, reproduces by means of planoblasts. The planoblasts of Perigonimus and Bougainvillia are not all alike, in fact they belong to two distinct medusoid families.

It would be an advantage to place Pruvotella grisea, Motz-Kossowska (1905), in the genus Bimeria. The generic character of Pruvotella, as given by Madame Motz-Kossowska, should make an excellent specific character.

I certainly prefer to place Hydroids, like Bougainvillia, with planoblasts, and Hydroids, like Bimeria, with sporosacs into separate genera, though there may be a few cases in which it is hard to draw the line. I notice that naturalists who have confined their attention solely to the trophosome completely disregard the nature of the gonosome in their classifications. They consider it is a matter of no importance whether the gonosome is a planoblast or a sporosac, and ignore the fact that medusæ have also a system of classification. I am strongly of the opinion that the gonosome should play an important part in the classification of Hydroids, especially in those Hydroids which liberate free-swimming medusæ.

Bimeria (Garveia) nutans (Wright).

This Hydroid occurred at Station I., 75 fathoms, on Sertularella polyzonias, and at Station II. it was common on Sertularia abietina. The colonies are without gonophores. 
Bimeria nutans is generally found in the form of an erect arborescent colony, but here it was growing as a creeping form, without branches. The hydrocaulus has become a creeping stolon giving off at intervals single hydranths, which are on fairly long stalks.

A change in the mode of growth is not uncommon among Hydroids, and is one of the difficulties in connection with the drafting of precise generic characters. Arborescent colonies of Syncoryne and Bougainvillia, when so placed in small aquaria that a branch is in contact with the glass, will frequently send out a "shoot which, on adhering to the glass, becomes converted into a stolon. The stolon develops single hydranths on long stalks, which seldom branch. The mode of growth of the new colony is distinctly that of a creeping form, whereas the old colony retains its arborescent growth.

\section{Bimeria vestita, Wright.}

At Station II., 75 fathoms, this species was fairly common on Sertularia abietina.

It can at once be recognised by having the lower half of each tentacle sheathed with a layer of perisarc. When the hydranths are in a contracted condition the sheath is scarcely visible, and then a colony looks like a little Bougainvillia.

Distribution. Firth of Forth (Wright, Allman); Yorkshire, Whitby (Hincks); Devonshire, Torbay and Salcombe (Hincks); Start Bay, 20-23 fathoms (E.T.B.); Lancashire, Morecambe Bay (Allman); Irish Sea (Thornely); Ireland, Lough Swilly (Duerden); Heligoland (Hartlaub, 1897); Mediterranean, near Banyuls (Motz-Kossowska).

Bimeria arborea, nova species. Plate I., figs. 1-3. Plate II.

At Station XIII., 412 fathoms, was taken a large tree-like Hydroid, which at first sight looked like an aged colony of Bougainvillia, but since the gonophores were found to be true sporosacs, it showed the generic character of Bimeria.

Description of the species. Trophosome-hydrocaulus well branched, attaining a height of about $3 \frac{1}{2}$ inches; branching irregular, with a tendency towards one plane; stems and branches fascicled; hydranths with about twelve tentacles in a single verticil; perisarc continued over the lower part of the hydranths in the form of a cup, into which the hydranth contracts. Gonosome-sporosacs situated on the hydrocaulus.

The specimens consist of a large colony (Plate II.) and several small pieces. It is quite probable that they all formed part of one colony, which the trawl had torn off above the root.

The stem and branches have a central axial tube surrounded by a large number of delicate auxiliary tubes. Apparently all the 
hydranths and gonophores are directly connected with the axial tube, and the auxiliary tubes only give rigidity to the stem and branches. The auxiliary tubes greatly increase the thickness of the stem and the principal branches, and extend, in decreasing numbers, almost to the extremities of the little branches, but do not run along the stalks of the hydranths.

The hydranths (Pl. I., Fig. 1) have rather a broad, cone-shaped hypostome surrounded by a single row of about twelve tentacles, but occasionally thirteen are present. It is not possible to say definitely that the tentacles during life naturally arrange themselves in two alternating series, one elevated and the other depressed, as in Bougainvillia. A few of the hydranths certainly show such an arrangement, but as nearly all the hydranths are in a contracted or semi-contracted condition, the tentacles are also contracted. Surrounding the lower part of the hydranth is a cup-like expansion of the perisarc, into which the hydranth withdraws on contraction. This cup is conspicuous owing to its being covered with very fine black or dark brown particles. A similar coating occurs in Bimeria vestita and Bougainvillia. The stalks of the hydranths are smooth, except at their origin, where there are a few slight wrinkles or corrugations. The axial tube is also smooth, but it is only exposed just at the tips of the branches.

The gonophores (Fig. 3) are situated upon the branches, and not upon the hydranths or their stalks. The male gonophore is globular in shape, and is upon a short pedicel. Sections (Fig. 2) show that it is a true sporosac. At the base of the spadix slight outgrowths of the endoderm indicate rudimentary radial canals, such as are found in the gonophore of Garveia mutans.

Bimeria biscayana, nova species. Plate I., figs. 4, 5 .

At Station XIII., 412 fathoms, six colonies of a small Hydroid, about $20 \mathrm{~mm}$. or less in height, were found attached to the coral Lophohelia. As the colonies have compound branches of considerable thickness for the size of the colonies, and are without gonosomes, they are probably at an early stage in their growth, and may reasonably be expected to grow to a much larger size.

Description of the species. Hydrocaulus compound, composed of series of tubes bearing individual hydranths. Some of the stems of the hydranths become branches. Hydranths with about ten tentacles in a single verticil. Perisarc continued over the lower part of the hydranth in the form of a small cup, into which the hydranth contracts. Gonosome unknown.

Theoretically, the main stem of the colony should be a single unbranched tube carrying a hydranth at its top. The hydranth 
manufactures the tube and also secretes inside it thin layers of perisare, which form a kind of coarse network (Fig. 4). Then from the root arise auxiliary tubes (stolons), which creep up the stem. From the auxiliary tubes bud forth numerous hydranths. At first the hydranths are sessile, and later on some develop a stalk; some are more vigorous than others and develop a long stalk, which becomes a branch, and is similar in structure to the original stem. Along the branches there creep from the root more auxiliary tubes bearing

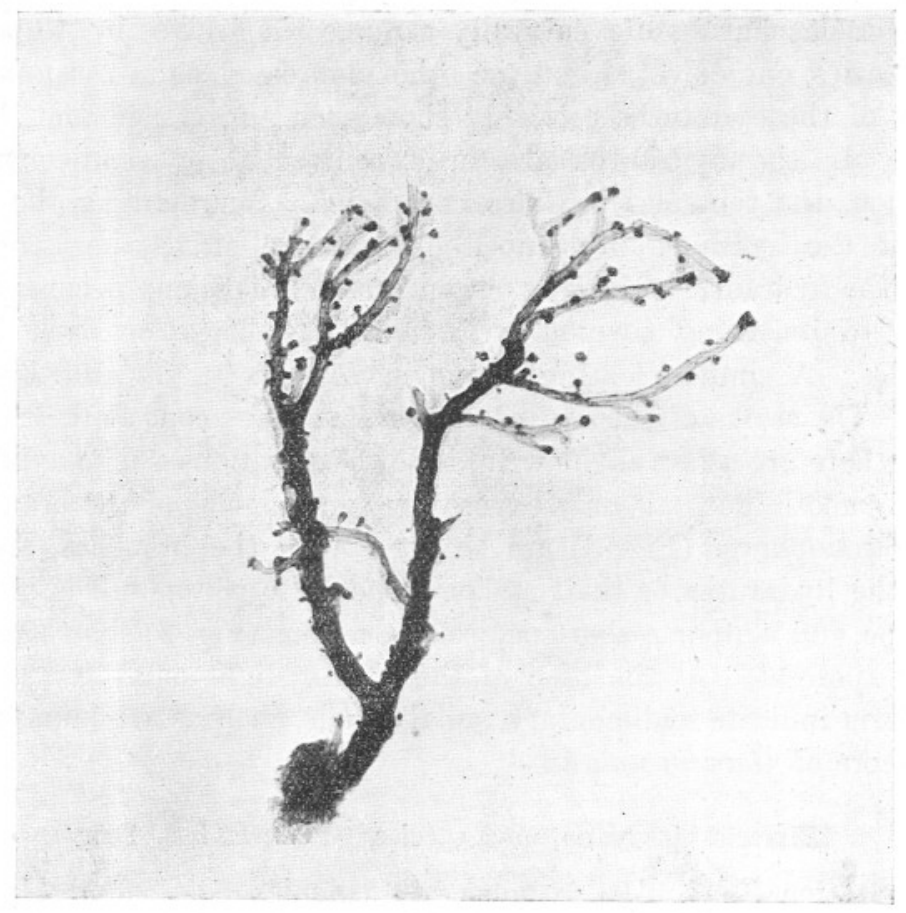

Fig. 1.

Bimeria biscayana, n. sp. $\times 4$.

hydranths. This process is repeated again and again, and results in the formation of an arborescent colony (Text Fig. 1).

The auxiliary tubes frequently anastomose with one another, and form a dense matted mass, which gives a considerable thickness to the principal branches.

The cœnosarcal tube of a hydranth, which forms a branch, apparently has no direct communication with the auxiliary tubes growing over the external surface of its perisarc. It is, however, in communication with other hydranths by means of its own auxiliary tube, from which it originally developed. The tube formed by the hydranth even when 
it lengthens into a branch does not produce lateral branches. Wherever I could trace the course of the internal cœnosarcal tube it always came from an auxiliary tube.

The auxiliary tubes are simply stolons arising from the root of the colony, growing over one another, and producing series of single hydranths, the stems of which do not develop hydranths or branch.

As all the hydranths are more or less contracted, their natural shape remains uncertain. They possess a broad conical hypostome, and generally ten tentacles, but occasionally eleven are present. The stalk of the hydranth is smooth, of about the same thickness throughout its whole length, and terminates in a slight extension to form the cup for the hydranth. The hydranths which remain sessile or nearly so upon the auxiliary tubes gradually become surrounded by tubes of a later growth, and embedded to such an extent that only their heads are visible.

Until the gonosome has been found, this species can only be provisionally regarded as a member of the genus Bimeria. As the Hydroid was found at a depth of over 400 fathoms, its gonophore is almost certain to be a sporosac.

\section{EUDENDRIDÆ.}

\section{Eudendrium ramosum (Linn.).}

At Station IV., 109 fathoms, a few colonies were taken. They are very small in size and attached to worm-tubes.

Distribution. Some recent foreign records:-California (Torrey). Antarctic Ocean, lat. $71^{\circ}$ S., long. $89^{\circ}$ W.; lat. $71^{\circ}$ S., long. $87^{\circ}$ W.; lat. $70^{\circ}$ S., long. $80^{\circ}$ W.; 220 to 300 fathoms. (Species marked (?), Hartlaub, Belgica Expedition, 1904.)

\section{Eudendrium rameum (Pallas).}

At Station II., 75 fathoms, a small colony about 1 inch in height was taken. At Station VII., over 444 fathoms, the trawl brought up a piece which had evidently, from the thickness of the stem, been broken off from a large colony. At Station XIII., 412 fathoms, several small colonies were taken, and also a branch about $3 \frac{1}{2}$ inches in height. Some of the colonies have gonophores.

Distribution. Some recent foreign records :-Arctic Ocean, off Bear Island, lat. $74^{\circ} 53^{\prime}$, long. $15^{\circ} 55^{\prime}$ E., 180 fathoms (Bonnevie). S.E. of Iceland, lat. $62^{\circ} 59^{\prime}$, long. $10^{\circ} 37^{\prime}$ W., 250 fathoms (Broch, 1903). Portugal (Nobre). Off West Coast of Morocco, $33^{\circ} 16^{\prime}$ N., $8^{\circ} 53^{\prime}$ W., 65 fathoms (Billard). California (Torrey). Chile, about lat. $42^{\circ} \mathrm{S}$. (Hartlaub, 1905). South Georgia, 135 fathoms (Jäderholm). 


\section{TUBULARID正.}

\section{Tubularia sp.}

At Station. II., 75 fathoms, a single Tubularia Hydroid was found attached to a worm-tube. It has the appearance of a young form.

\section{CALYPTOBLASTEA. CAMPANULARID压.}

Clytia johnstoni (Alder).

A few colonies with gonophores were found at Stations I. and II., 75 fathoms. They were attached to Sertularia abietina and to other large Hydroids.

The bathymetrical distribution of Clytia johnstoni is from the shore down to about 100 fathoms.

\section{Campanularia hincksii, Alder.}

This species was fairly. common at most of the stations, extending from 75 fathoms down to over 444 fathoms. It was usually attached to Sertularella, occasionally on Antennularia, but only once seen on a Diphasia. Colonies with gonophores were taken at Station II.

Campanularia hincksii is similar to Clytia johnstoni in its mode of growth and habitat, but differs in its method of reproduction. The gonophores contain fixed sporosacs which mature their products within the gonangium. Clytia liberates free-swimming medusæ which belong to the medusoid genus Phialidium.

It does not occur so close to shore as Clytia, but extends to a much greater depth.

Distribution. Some recent foreign records :-Off east coast of Greenland, $74^{\circ} 7^{\prime}$ N., $19^{\circ} 4^{\prime}$ E. ; 50 fathoms; $0 \cdot 19^{\circ}$ C. Off Norwegian coast, $62^{\circ} 17^{\prime}$ N., $4^{\circ} 57^{\prime}$ W. 145 fathoms (Broch, 1903). Morocco, off Cape Spartel, 60 fathoms (Billard).

Campanularia raridentata, Alder.

A few hydranths resembling Alder's figure were seen on Sertularella, and on a broken shell at Station IV.

\section{CAMPANULINIDE.}

\section{Calycella fastigiata (Alder).}

A few colonies were found attached to Sertularella and to the roots of Diphasia alata, 75-240 fathoms.

Distribution. Some foreign records:-Norway, Aelesund, 55-100 fathoms (Bonnevie). Gulf of Gascogne, 225 fathoms. Off west coast of Morocco, $33^{\circ} 16^{\prime}$ N., $8^{\circ} 53^{\prime}$ W.; 60 fathoms (Billard). 


\section{LAFOËID压.}

Lafoëa dumosa (Fleming).

The erect form (var. robusta) was common at Station II., but scarce at Station V. The creeping form also occurred at Station II., and on Lophohelia at Station XIII., 412 fathoms.

The deepest record for this species is 450 fathoms, off Sombrero Island, West Indies (Challenger Expedition).

\section{Lafoëa fruticosa (M. Sars), var. gracillima, Alder.}

This species was very scarce; just a few colonies from Stations I. and II., 75 fathoms. At the second station it was growing over worm-tubes.

There appears to be a difference of opinion as to whether Lafoëa gracillima, Alder, and Lafö̈a fruticosa, Sars, are the same species or distinct species. Lafö̈a gracillima has its hydrotheca on a stalk which has one or two very loose twists, but Lafoëa fruticosa has three or four distinct spiral twists. The specimens in this collection belong to Alder's type, which is the type found in the English Channel, and which has usually been called Lafoëa fruticosa.

Distribution. Jäderholm has recently recorded Lafö̈a gracillima for Falkland Islands and South Georgia.

One of the deepest records for Lafoëa gracillima is 274 fathoms, off the Norwegian coast, $62^{\circ} 30^{\prime}$ N., $1^{\circ} 56^{\prime}$ E. (Broch, 1903).

\section{Lafoëa pinnata, G. O. Sars.}

Lafoëa pinnata, G. O. Sars, 1873, p. 116, Tab. IV. figs. 25-28; Bonnevie, 1899, p. 69, Pl. VI. fig. 1.

Lafoëa halecioides, Allman, 1874, p. 472, Pl. LXVI. fig. 1.

Lictorella halecioides, Pictet et Bedot, 1900, p. 16, Pl. III. figs. 4, 5.

Lictorella pinnata, Broch, 1903; Broch, 1905, p. 11, fig. 3.

This species was taken at Station XIII., 412 fathoms, and was either growing over Eudendrium rameum, or fixed to the coral Lophohelia.

It was first described by G. O. Sars, who found it on Eudendrium rameum in the Hardangerfjord, on the coast of Norway. In 1874 Allman described a new species of Lafö̈a under the name of Lafö̈a halecioides, which was found by the Porcupine Expedition in the Faeroe Channel, and this appears to me to be identical with Lafoëa pinnata.

Allman (1888), in the Report on the Hydroida of the Challenger Expedition, considered a Hydroid from Torres Straits, North Australia, to be identical with Lafoëa halecioides from the Faeroe Channel, and on account of the structure of the hydrotheca of the Australian specimen, he transferred Lafoëa halecioides to a new genus called Lictorella. 
Through the kindness of Mr. R. Kirkpatrick, I have examined at the British Museum the specimen of Lictorella halecioides from Torres Straits. It is not like Lafoëa pinnata, and it is not like Allman's figure of Lafoëa halecioides from the Faeroe Channel.

Pictet and Bedot record the occurrence of Lictorella halecioides in the Bay of Biscay. Their description and beautiful figures show that they refer to the form originally described by Allman from the Faeroe Channel.

The distinction between the two genera Lafoëa and Lictorella rests entirely upon the structure of their hydrothecæ. In Lafoëa the cavity of the hydrotheca is directly continuous with that of the stem or peduncle, but in Lictorella the cavity is distinctly differentiated from that of the peduncle.

In the lower part of the hydrotheca of Lafoëa pinnata there is a fine transverse circular line on the inner side of the perisarc. The line is more readily seen when the hydrothecæ are empty, and, better still, when the perisare has been lightly stained. Two circular lines, close together, are not uncommon, and occasionally a hydrotheca was seen without a circular line. In mounted specimens one usually sees this line and nothing more, but occasionally in an empty hydrotheca a very fine membrane, with a central hole, was found stretching across the hydrotheca. The circular line is a very slight thickening of the perisarc, to which this membrane is attached. When the colony is alive the membrane extends from the body of the hydranth to the perisarc of the hydrotheca, and shuts off the lower part of the hydrotheca from the exterior. The membrane is so thin and delicate that it usually disappears on the death or absorption of the hydranth. Levinsen (1893) has noticed a similar membrane in Lafoëa fruticosa. This membrane has commonly been called a diaphragm and considered homologous with the diaphragm of a typical Campanularian Hydroid. To compare this delicate membrane with the firm perisarcal diaphragm which forms the bottom of the hydrotheca of a Campanularia is likely to cause confusion. The membrane is not at the bottom of the hydrotheca, and it does not, on account of its pliability, in any way limit the contracting back of the hydranth; when the hydranth of a Lafoëa is contracted back it does not rest upon the diaphragm like a Campanularia, but contracts back below the diaphragm to the bottom of the hydrotheca.

Lictorella halecioides from Torres Straits has a typical Campanularian diaphragm. Its hydrotheca, with a thick basal wall, is upon a short peduncle, and the cavity of the hydrotheca is distinctly differentiated from that of the peduncle.

Description of Lafoëa pinnata. This Hydroid has two modes of 
growth: (a) A creeping form which occurs on Eudendrium. In this form the stolon either gives off stems bearing only hydranths, or stems with lateral branches which carry the hydranths. The stem is either simple, monosiphonic, or fascicled. A fascicular stem has usually only one or two auxiliary tubes. (b) An erect form which is distinguishable from the creeping form by the main stem being thick and composed of many auxiliary tubes, and by the presence of thick fascicular branches which give off branchlets to bear the hydranths.

Sars has described and figured the creeping form on Eudendrium. Allman, Bonnevie, and Bedot, figure the erect form, which reaches a height of $70 \mathrm{~mm}$. In this collection both forms occur; the erect form is similar to the figures given by Allman and Bedot.

The peduncle of the hydrotheca has the appearance of being twisted near its base. There is not a distinct joint, but rather a corrugation of the perisarc. Occasionally a peduncle was seen without the slightest trace of even a wrinkle, but peduncles with several transverse corrugations or even with two or three distinct rings were more frequently seen.

The hydrothecæ are alternately situated upon the stem, and all turn towards the same side of the colony. They frequently show several rings of growth near their orifice. A single hydrotheca is also present in the axil of the branches.

In addition to the ordinary hydrothecæ, there are very minute pedunculated cups, resembling somewhat in shape and size the sarcothecæ of Perisiphonia pectinata (Pictet and Bedot, 1900, Pl. IV. figs. $2 b, 2 c)$. They occur either at the axil of a branch, or at the base of the peduncle of a hydrotheca, or on an auxiliary tube of the stem. They are, however, extremely scarce; one branch may have two or three, and another none at all. Some have, undoubtedly, been broken off, as minute holes were found in the perisare in the places where they should occur, but even the holes are very scarce. A few of the sarcothecæ contain a little conosare which is usually in a contracted or dilapidated condition.

The existence of nematophores in Lafoëa pinnata has not been previously noticed, but before changing the generic name again it would be well to know if similar nematophores occur in specimens from other localities, especially off the Norwegian coast. If so, then I would suggest that the species be transferred to the genus Zygophylax, Quelch. There seems to be a close relationship between my specimens of Lafoëa pinnata and Zygophylax biarmata (Billard, 1907).

All the colonies are without gonosomes. Bonnevie has figured the gonosome, and it belongs to the Scapus type.

Distribution. Arctic Ocean, $71^{\circ} 45^{\prime}$ N., $15^{\circ} 41^{\prime}$ E., 620 fathoms 
(1134 metres), $0.97^{\circ}$ C.; $72^{\circ} 27^{\prime}$ N., $35^{\circ} 1^{\prime}$ E., 136 fathoms (249 metres), $0^{\circ}$ C. (Bonnevie). Norway, Hardangerfjord, 90-100 fathoms (Sars). Between Iceland and Greenland, $66^{\circ} 42^{\prime}$ N., $26^{\circ} 40^{\prime}$ W., 320 fathoms, $+0 \cdot 11^{\circ}$ C. (Broch, 1903). Faeroe Channel, 61 $11^{\prime}$ N., $2^{\circ} 21^{\prime}$ W., 345 fathoms, $30^{\circ} \mathrm{F} . ; 61^{\circ} 21^{\prime}$ N., $3^{\circ} 44^{\prime}$ W., 640 fathoms, $30^{\circ}$ F. (Allman, 1874). Off north-west of Scotland, 59 $28^{\prime}$ N., $8^{\circ} 1^{\prime}$ W., 600-700 fathoms (1100-1300 metres) (Broch, 1903). North-west of Faeroe Islands (Broch, 1903). Bay of Biscay, off north coast of Spain, $43^{\circ} 4^{\prime} \mathrm{N}$., $8^{\circ} 55^{\prime}$ W., 80 fathoms (Pictet and Bedot).

\section{Filellum serpens (Hassall).}

Lafoëa serpens, Bonnevie, 1899.

This species was very common on Sertularella abietina at Stations II. and IX., 75-240 fathoms.

Both Levinsen and Bonnevie state that the gonosome belongs to the Coppinia type, and a figure of it is given by Bonnevie.

Filellum serpens has recently been recorded by Jäderholm from the Falkland Islands and Tierra del Fuego. It was found by the Norwegian North Atlantic Expedition at many different stations, 10-328 fathoms (Bonnevie).

\section{Perisiphonia pectinata, Pictet et Bedot.}

Perisiphonia pectinata, Pictet et Bedot, 1900, p. 18, Pl. IV. V.

There is only one specimen of this interesting Hydroid, which was taken at Station XIII., 412 fathoms, and found attached to the coral Lophohelia. The main stem is about $20 \mathrm{~mm}$. in height, and has twelve alternating branches.

There are some exceedingly beautiful figures of this species drawn by Bedot, who believes that his specimens, taken in the Gulf of Gascogne and at the Azores, are identical with those described by Allman (1888) under the name of Perisiphonia pectinata. Allman has described two species of Perisiphonia-P. filicula from the Azores and Australia, and $P$. pectinata from off the coast of New Zealand. My specimen agrees very well with Bedot's figures, but I am not sure that it is identical with either of Allman's species.

The stem and branches have a principal axial tube from which the hydrothecæ arise, and it is surrounded by a number of auxiliary tubes, which do not bear hydrothecæ, but numerous minute sarcothecæ. The presence of sarcothecæ is the characteristic feature of the genus.

The hydrothecæ are adnate for about half their length to the axial tube. According to Allman, a pedunculated hydrotheca is one of the characters of the genus, but I think that this detail might be omitted from the generic characters and passed down to the species. At the 
base of the hydrotheca there is a transverse ring, which indicates the presence of a diaphragm similar to the one mentioned in Lafoëa pinnata. The hydrothecæ have not the shape or position of those figured by Allman, but are similar to those figured by Bedot. Many of the hydrothecæ show circular rings of growth near their orifice.

The shapes of the sarcothecæ are similar to those figured by Bedot, but they are not like the long sarcothecæ on the auxiliary tubes of Allman's species. So far as I know, no one has yet examined a living Perisiphonia, so that the structure and form of the supposed sarcostyles are unknown.

Bedot fortunately found a specimen bearing a gonosome, which was previously unknown. It belongs to the Coppinia type, and a beautiful figure is given of it.

Cryptolaria humilis, Allman.

Cryptolaria humilis, Allman, 1888, p. 39, Pl. XVIII. fig. 1.

The collection contains only a fragment from the upper part of a colony. It was taken at Station XIII., 412 fathoms. The hydrothecæ are similar to those of Cryptolaria humilis as figured by Allman, and they are also like the hydrothecæ of C. conferta, Allman, and C. crassicaulis, Allman. It would be well to have these three species united, and a few more with them.

Distribution. C. humilis: off the Azores, $38^{\circ} 30^{\prime} \mathrm{N} ., 31^{\circ} 14^{\prime} \mathrm{W}$., 1000 fathoms (Allman, 1888). C. conferta: off Cuba, 450 fathoms (Allman, 1877); off the Azores, 70-250 fathoms (Pictet et Bedot); Gulf of Gascogne, 225 fathoms; off West Coast of Morocco and Soudan, Cape Spartel to Cape Garnet, 225-400 fathoms (Billard). C. crassicornis: off Ascension Island, 420 fathoms (Allman, 1888).

Cuspidella grandis, Hincks.

This species occurred at Station I., 75 fathoms, on Sertularella polyzonias. At Station IV., 109 fathoms, it was fairly common on Sertularella and Diphasia alata.

Cuspidella costata, Hincks.

This species was only taken at Station I., 75 fathoms, and was rather scarce.

\section{HALECID压.}

Halecium sessile, Norman.

A single specimen was taken at Station XIII., 412 fathoms. It is about $2 \frac{1}{2}$ inches in height, and has evidently lost some of its branches. The main stem is thick and fascicled; the principal branches are also fascicled and irregular in position. 
The hydrothecæ are sessile, and around their orifice there are a number of fine lines. These lines look like a striated band, but on being subjected to a higher magnification each line is seen to be a projecting rim and to represent a rudimentary hydrotheca.

The gonangia (male) are very long and slightly curved. They are situated on the side of the hydrothecæ, either singly or in pairs. Their distal end is rounded, and the proximal end tapers towards a joint which is closed to the hydrotheca. The male gonangium agrees with Bonnevie's description. The female form is still unknown.

Distribution. Scotland, The Minch, in deep water (Hincks, 1868). Norway, Bodo, Lofoden, 55-100 fathoms (Bonnevie).

\section{SERTULARID压.}

Sertularella polyzonias (Linn.).

This species occurred at all the stations, except at the two over 400 fathoms. It was usually attached to worm-tubes, shells, and occasionally to small stones or to another Hydroid. A few of the colonies taken at Station II. bear gonophores.

Jäderholm has recently recorded this species for the Falkland Islands and South Georgia.

According to Nutting, the greatest depth recorded for this species is 353 fathoms in the North Atlantic, off Florida.

Sertularella gayi (Lamouroux).

Large colonies, some of which are loaded with gonophores and carry their ova in acrocysts, were taken at Station VII., over 444 fathoms. The species was also fairly common at Station XIII., 412 fathoms.

Some of the colonies have very thick stems, and are evidently of a great age. Even quite small colonies have thick stems and branches, and have the appearance of old colonies producing a new growth of shoots.

Both Sertularella polyzonias and S. gayi are common species on the Eddystone Grounds, 30-35 fathoms, yet on this cruise S. gayi was only taken at the two stations over 400 fathoms, and there S. polyzonias was absent.

Sertularella gayi has been taken in the Faeroe Channel at the depth of 605 fathoms (Allman, 1874).

Diphasia pinaster (Ellis and Solander).

A few colonies, without gonangia, were taken at Stations I., II., IV., and V., 75-109 fathoms. Some were attached to worm-tubes.

Distribution. Hebrides, 40 fathoms; off Mull of Galloway, 110140 fathoms; Dogger Bank; Jersey; Dublin Bay; and other places 
(Hincks, 1868). South of the Eddystone (Bourne). Norway, 200 fathoms (Broch, 1903). Portugal (Nobre). Gulf of Gascogne, 100 fathoms; Azores, 75 fathoms (Pictet and Bedot). Off the Azores, 450 fathoms (Allman, 1888). Morocco, Cape Spartel, 60 fathoms; Cape Verde Islands, 220-320 fathoms (Billard).

Diphasia tamarisca (Linn.).

At Stations I. and II., 75 fathoms, a few small colonies and fragments were taken. Some of the colonies have gonophores.

Bonnevie records this species along the Norwegian coast from Kristiandsund to Hammerfest, and off the north-west coast of Norway in lat. $69^{\circ} 44^{\prime}$, long. $16^{\circ} 15^{\prime}$ E., 650 fathoms, $0.66^{\circ}$ C.; and $71^{\circ} 45^{\prime} \mathrm{N}$., $15^{\circ} 41^{\prime}$ E., 622 fathoms, $0.97^{\circ} \mathrm{C}$.

\section{Diphasia pinnata (Pallas).}

A splendid colony was taken at Station III., 75 fathoms. There are over a dozen shoots, the largest about 6 inches in height, and several are loaded with female gonophores.

The colony when alive was of a deep carmine colour, which slowly dissolved out irf alcohol, and after its complete removal the colony became a dark brownish colour.

Distribution. South coast of Devon and Cornwall, about 30-40 fathoms (Hincks). As this species was not taken by the Challenger Expedition, and is not mentioned in recent foreign records, its occurrence outside the areas mentioned above is very doubtful.

\section{Diphasia alata (Hincks).}

At Station IV., 109 fathoms, a large colony, with many shoots and branches, up to 5 inches in height, and a small colony were taken. Both colonies were attached to worm-tubes. At Station V. several large branches were again taken.

The main stem is strengthened by a number of auxiliary tubes, which run along one side of it, and decrease in number towards the distal ends.

Several of the large shoots bear female gonosomes. The gonangia are similar to those of the male.

Distribution. Norway, Stavanger, 50-100 fathoms (Bonnevie). Shetlands, 40 fathoms (Hincks). Cornish coast (Hincks). Ireland, west coast, 43 fathoms (Duerden). Bay of Biscay, Gulf of Gascogne, 75-164 fathoms; Azores, 75-174 fathoms (Pictet and Bedot). Gulf of Gascogne, 225 fathoms (Billard).

\section{Sertularia abietina (Linn.).}

Abietinaria abietina, Nutting, 1904.

A fine old colony, closely covered with other small Hydroids, 
was taken at Station II., 75 fathoms, and some large branches at Station III. At Station IX., 240 fathoms, a few fragments were secured.

Broch (1903) records this species at 250 fathoms in lat. $62^{\circ} 59^{\prime} \mathrm{N}$., long. $10^{\circ} 37^{\prime} \mathrm{W}$.

\section{Hydrallmania falcata (Linn.).}

A few fragments were obtained at Station I., 75 fathoms.

\section{PLUMULARID压.}

Plumularia elegantula, G. O. Sars.

Plumularia elegantula, G. O. Sars, 1873, p. 103, Tab. III. figs. 9-14; Bonnevie, 1898, p. 15; Bonnevie, 1899, p. 90.

This species occurred at Station VII., over 444 fathoms, and at Station XIII., 412 fathoms. At the first station only two plumes were taken. The largest measures $35 \mathrm{~mm}$. in length, and has a few empty gonangia on the stem. At the second station several young colonies were found attached to the coral Lophohelia.

It is very likely that this species is a deep-water variety of Plumularia pinnata. It agrees with the latter species in every detail, except that the internodes of the hydrocladia are nearly twice as long. The hydrothecæ are smaller in size, and are situated at the distal end of the internodes. Their position is probably due to the lengthening of the internode at its proximal end. It is the length of the internodes that gives the hydrocladia a more delicate and more slender appearance than that seen in the littoral Plumularia pinnata.

Distribution. Norway, Kristiania to Bodo, 55-200 fathoms (Bonnevie, 1899).

\section{Plumularia setacea (Ellis).}

At Station I., 75 fathoms, very small colonies bearing gonangia were found on Aglaophenia and Antennularia.

At Station XIII., 412 fathoms, several little colonies with gonangia were attached to Plumularia frutescens.

Distribution. Some recent foreign records :-Norway, 55-110 fathoms (Bonnevie); Azores, 174 fathoms (Pictet et Bedot); Florida (Nutting); California (Nutting); Puget Sound (Torrey); Chile (Hartlaub); Ceylon (Thornely); New Zealand (Hartlaub, 1901); Japan (Jäderholm, 1896).

\section{Plumularia frutescens (Ellis and Solander).}

A few short branches bearing gonophores were taken at Station XIII., 412 fathoms.

Bonnevie records this species for the coast of Norway, 20-160 fathoms. 
Antennularia antennina (Linn.).

Small colonies were fairly common at Station I., 75 fathoms, but scarce at Station II.

Distribution. Recent foreign records:-Norway, 100-200 fathoms (Bonnevie); Bay of Biscay, Gulf of Gascogne, 10-35 fathoms (Pictet et Bedot); Portugal (Nobre); North Atlantic, off the American coast, lat. $42^{\circ}$ N., long. $65^{\circ}$ W., 65 fathoms; lat. $35^{\circ}$ N., long. $75^{\circ}$ W., 71 fathoms (Nutting).

\section{Antennularia ramosa (Lamarck).}

A few fragments were taken at Station II., 75 fathoms,

Distribution. Recent foreign records:-Bay of Biscay, Gulf of Gascogne, 35-75 fathoms (Pictet et Bedot); Portugal (Nobre); Azores, 75 fathoms (Pictet et Bedot).

Antennopsis, Allman, 1877.

Generic character (Nutting, 1900). Trophosome-stem jointed; cœnosarc not canaliculated; hydrocladia scattered irregularly over the stem, sometimes approaching a verticillate arrangement. Gonosomegonangia borne in the axils of the hydrocladia, without protective appendages.

Antennopsis norvegica (G. O. Sars).

Heteropyxis norvegica, G. O. Sars, 1873, p. 104, Tab. III. figs. 15-22.

Antennularia norvegica, Bonnevie, 1899, p. 97.

Antennularia norvegica, Broch, 1903 ; Broch, 1905, p. 24; Billard, 1907, p. 217.

At Station XIII., 412 fathoms, a few colonies about $15-35 \mathrm{~mm}$. in height were found upon Lophohelia.

In young colonies the arrangement of the hydrocladia on the stem is pinnate, as in the genus Plumularia. The same arrangement is found at the bottom of the larger plumes, but as the stem grows in length the hydrocladia no longer remain in the same plane. They project out in pairs, either alternate or opposite, at an angle of about forty-five degrees. At the distal end of the plume the hydrocladia become closer together and more irregular in position, and scattered in all directions round the stem. This irregular arrangement of the hydrocladia led Bonnevie to place the species in the genus Antennularia.

Nutting in his revision of the Plumularidæ has restricted the genus Antennularia to species with a canaliculated stem, and retains the genus Antennopsis for species with a simple or fascicled stem.

The specimens from the Bay of Biscay have a simple, monosiphonic stem. Bonnevie, however, states that the main is compound, which I interpret to mean a fascicled stem. 
The internodes of the main stem are very irregular in length; some are quite long, carrying about eight hydrocladia, others are very short, with only two or three hydrocladia.

The nematophores are bithalamic and rather small. On each internode of the hydrocladia there are three, two situated in front of the hydrotheca and one behind it. There are also two in the axil of the hydrocladia, and several scattered over each internode of the main stem.

The gonangia are in the axil of the hydrocladia, usually one or two, but occasionally three are present. They are curved downwards, and contain a single ovum.

Distribution. Norway, Kristianfjord, 50-60 fathoms; Hardangerfjord, 90-100 fathoms (Sars). North Atlantic, off the Norwegian coast, $61^{\circ} 41^{\prime}$ N., $3^{\circ} 19^{\prime}$ E., 219 fathoms, $+6^{\circ}$ C.; $62^{\circ} 44^{\prime}$ N., $1^{\circ} 48^{\prime}$ E., 411 fathoms, $-1 \cdot 6^{\circ}$ C.; $64^{\circ} 48^{\prime}$ N., $6^{\circ} 36^{\prime}$ E., 155 fathoms, $+6 \cdot 9^{\circ}$ C. (Bonnevie). North Sea, $57^{\circ} 11^{\prime}$ N., $1^{\circ} 50^{\prime}$ W., 55 fathoms, $58^{\circ} 0^{\prime}$ N., $3^{\circ} 24^{\prime}$ E., 50 fathoms; $57^{\circ} 9^{\prime}$ N., $1^{\circ} 30^{\prime}$ E., 50 fathoms, $+6 \cdot 15^{\circ}$ C. (Broch, 1905); $62^{\circ} 16^{\prime}$ N., $6^{\circ} 6^{\prime}$ W., 60 fathoms (Broch, 1903). South-west of Toulon, 245 fathoms (Billard).

Aglaophenia myriophyllum (Linn.).

Lytocarpus myriophyllum, Allman, 1883.

Thecocarpus myriophyllum, Nutting, 1900.

About thirty specimens were taken at Station I., 75 fathoms, and a few at Station II.

Distribution. Recent foreign records:-Off the coast of Norway, 200-400 fathoms (Bonnevie). Bay of Biscay, 50-135 fathoms; Azores, 70 fathoms (Pictet et Bedot). Portugal (Nobre). South of Madeira, 55 fathoms; off the west coast of Morocco, 300 fathoms; Cape Verde Islands, 220-320 fathoms (Billard).

\section{LITERATURE,}

Allen, E. J. 1899. On the Fauna and Bottom-Deposits near the Thirty-Fathom Line from the Eddystone Grounds to Start Point. Journ. Marine Biol. Assoc., vol. v. pp. 365-452. 16 charts. Plymouth.

Allman, G. J. 1871-1872. A Monograph of the Gymnoblastic or Tubularian Hydroids. Ray Soc. London.

Allman, G. J. 1874. Report on the Hydroida collected during the Expeditions of H.M.S. Porcupine. Trans. Zool. Soc. Lond,, vol. viii. pp. 469-481. Pls. LXV.-LXVIII.

Allman, G. J. 1883-1888. Report on the Hydroida dredged by H.M.S. Challenger. Part i. Plumularidæ, 1883, vol. vii. 55 pp. 20 pls.

Part ii. Tubularinæ, Campanularinæ, etc., 1888 , vol, xxiii. 159 pp. 39 pls.

Brulard, A. 1907. Hydroides. Expéditions scientifiques du Travailleur et du Talisman, tom. viii. pp. 153-243. 21 text figures. Paris: 
Bonnevie, Kristine. 1898. Neue norwegische Hydroiden. Bergens Mus. Aarbog, 1898, No. 5. 16 pp. 2 Tafn.

Bonnevie, Kristine. 1899. The Norwegian North Atlantic Expedition, 1876-1878. Hydroida, No. 26.103 pp. 8 pls. Christiania.

Bourne, G. C. 1890. Notes on the Hydroids of Plymouth. Jour. Mar. Biol. Assoc. (N.S.), vol. i. pp. 391-398. Pl. XXVI. Plymouth.

Broch, H. 1903. Die von dem norwegischen Fischereidampfer Michcel Sars in den Jahren 1900-1902 in dem Nordmeer gesammelten Hydroiden. Bergens Mus. Aarbog, 1903, No. 9.14 pp. 4 Tafn.

Broch, H. 1905. Nordsee-Hydroiden von dem norwegischen Fischereidampfer Michael Sars in den Jahren 1903-1904 gesammelt, nebst Bemerkungen über die Systematik der Tekaphoren Hydroiden. Bergens Mus. Aarbog, 1905, No. 6. 28 pp. 2 Tafn.

Duerden, J. E. 1896. The Hydroids of the Irish Coast. Proc. R. Dublin Soc., vol. viii. pp. 405-420.

Hartlaub, C. 1897. Die Hydromedusen Helgolands. Wiss. Meeresunters. deutsch. Meere, Bd. ii. pp. 449-536. 10 Tafn.

Hartlaub, C. 1901. Hydroiden aus den Stillen Ocean. Zool. Jahrbüch, Bd. xiv. pp. 349-379. Taf. XXl,-XXII.

Hartlaub, C. 1904. Hydroiden. Résultats du Voyage du Belgica, 1897-1899 (Expédition antarctique). 19 pp. 4 pls. Antwerp.

Hartlaub, C. 1905. Die Hydroiden der magalhaensischen Region und chilenischen Küste. Zool. Jahrbüch, Suppl. VI. Dr. L. Plate, Fauna Chilensis. Bd. iii. pp. 497-714. 142 text figures.

Hincks, T. 1868. A History of the British Hydroid Zoophytes. London.

JäDerHoLM, E. 1896. Ueber assereuropäische Hydroiden des Zoologischen Museums der Universitäts Upsala. Bihang Svensk. Vet. Akad. Handl. Bd. xxi. Afd. 4, No. 6. Stockholm.

JÄDERHoLm, E. 1905. Hydroiden aus Antarktischen und Subantarktischen Meeren. Schwedischen Südpolar-Expedition, 1901-1903, Bd. v. Lief. 8.41 pp. 14 Tafn. Stockholm.

Marine Biological Association. 1904. Plymouth Marine Invertebrate Fauna. Being Notes of the Local Distribution of Species occurring in the Neighbourhood. Compiled from the Records of the Laboratory. Journ. Mar. Biol. Assoc., vol, vii. pp. 155-298.

Motz-Kossowska, S. 1905. Contribution à la Connaissance des Hydraires de la Méditerranée occidentale. I. Hydraires gymnoblastiques. Arch. Zool. expérimentale et générale, ser. 4, tom. iii. pp. 39-98. Pl. III. Paris.

Nobre, A. 1903. Subsidios para o estudo da fauna marinha do norte de Portugal. Ann. Sci. nat. Porto., vol. viii. pp. 37-94. 1 pl. and pp. 153-160.

Nutring, C. C. 1900. American Hydroids. Pt. i. Plumularidæ. 142 pp. 34 pls. Special Bulletin Smithsonian Instit. Washington.

Nutring, C. C. 1904. American Hydroids. Pt.ii. Sertularidæ. Special Bulletin Smithsonian Instit. 151 pp. 41 pls.

Picter, C., et Bedot, M. 1900. Hydraires provenant des campagnes de l'Hirondelle (1886-1888). Result. Camp. scient. Albert de Monaco, fasc. xviii. 58 pp. 10 pls. Monaco.

Sars, G. O. 1873. Bidrag til Kundskaben om Norges Hydroider. VidenskabsSelskabet. Forhandl., 1873, pp. 91-150. Tab. II.-V. Christiania. 
Thornely, Laura R. 1904. Report on the Hydroida. Ceylon Pearl Fisheries, pt. ii. pp. 107-126. 3 pls. Royal Soc., London.

Torrey, H. B. 1902. The Hydroida of the Pacific Coast of North America. Univ. California Publications. Zool., vol. i. pp. 1-104. 11 pls. Berkeley California,

\section{EXPLANATION OF PLATE I.}

Figs. 1-3. Bimeria arborea, nova species, p. 20.

Fig. 1. The hydranth. $\times 100$.

Fig. 2. Portion of a branch. $\times 9$. G., Gonophore.

Fig. 3. The male gonophore. Longitudinal section. $\times 150$.

Ec., Ectoderm. En., Endoderm. G., Gonads. R., Rudimentary radial canals. P., Perisarc.

Figs. 4-5. Bimeria biscayana, nova species. p. 20.

Fig. 4. Transverse section of the stem of a hydranth. $\quad \times 180$.

A., Auxiliary tubes. Ec., Ectoderm. En., Endoderm. P., Perisarc. $\mathrm{P}^{1}$, Inner layer of perisarc. $\mathrm{P}^{2}$, Intermediate layers of perisare forming a coarse mesh-work.

Fig. 5. Portion of a branch drawn to show the arrangement of the hydranths and the auxiliary tubes. $\times 40$.

S., Stem of a hydranth which has grown into a branch. A., Auxiliary tubes growing over the branch and bearing hydranths $\mathrm{H}^{1}$. $\mathrm{A}^{1}$, Auxiliary tubes which are probably for the upper parts of the colony. H., Hydranths which give rise to branches and are connected with auxiliary tubes on $\mathrm{S}$. $\mathrm{S}^{*}, \mathrm{~A}$ transverse section of the stem in this position is shown in Fig. 4.

\section{PLATE II.}

Bimeria arborea. Collotype plate from a photograph by the author. $\times 1 \cdot 4$. 
Journ. Mar. BIOL. Assoc. Vol. VIII.

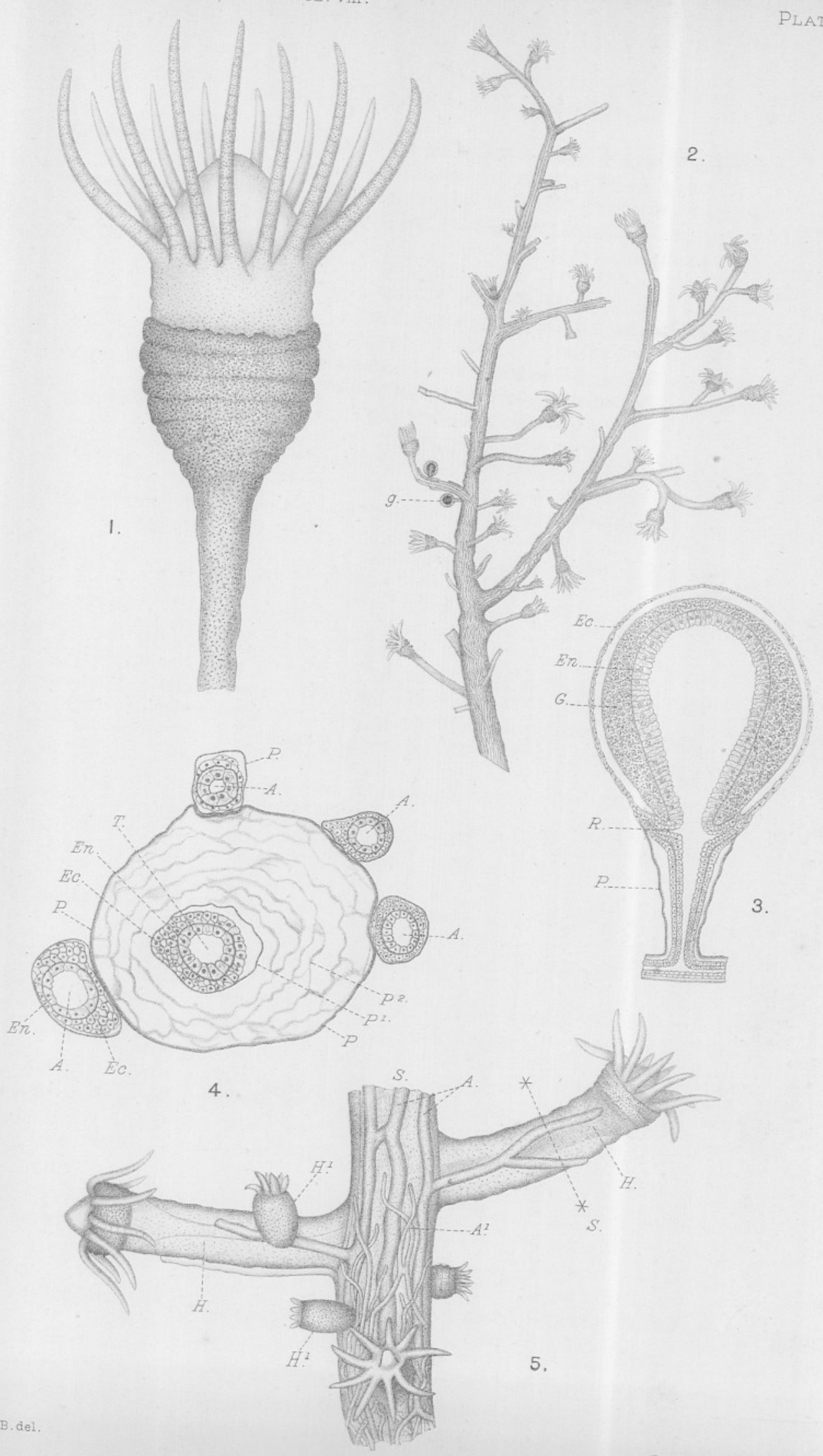




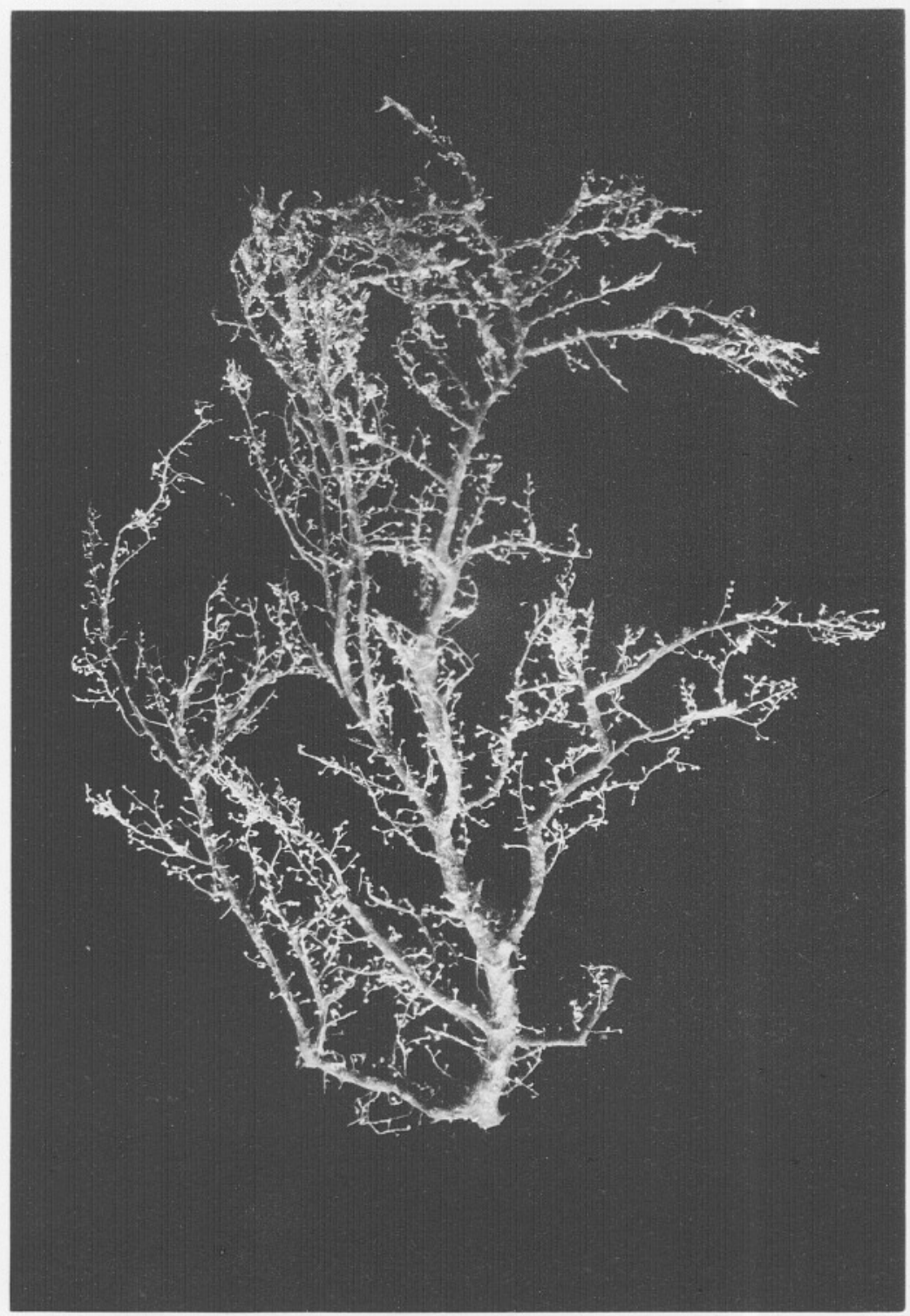

